\title{
Formulation of Antioxidant Gel Preparations on the Cherry (Muntingia calabura L.) Extract from Kupang, East Nusa Tenggara Based on AQUPEC 505 HV
}

\author{
Ni Nyoman Yuliani ${ }^{*}$, Jefrin Sambara, Yulius Baki Korassa \\ Department of Pharmacy, Kupang Health Polytechnic of Health Ministry, Indonesia \\ ${ }^{*}$ Correspondence E-mail : y.ninyoman@gmail.com
}

\begin{abstract}
Cherry (Muntingia calabura L.) from Kupang, East Nusa Tenggara is a local fruit in Indonesia which has many benefits for health. One of compounds contained in Cherry is polyphenol functioning as antioxidant. The purpose of this study was to obtain information about antioxidant activity contained in Cherry in the form of extract or gel preparations with different base of aqupec $505 \mathrm{HV}$ with routine comparison. Methods: The method used in this study was quantitative analysis. The cherry was extracted by using reflux method with $70 \%$ ethanol solvent and the quantitative testing of antioxidant activity through DPPH method with methanol solvent. For the qualitative one, Thin Layer Chromatography was used with mobile phase of butanol: acetic acid: water (4:1:5). Results: From the physical quality testing of gel preparations, it was obtained stable result in the room-temperature storage and the result of physical quality testing of formula 3 was totally effective to be used on the skin. From the antioxidant activity testing of Cherry extract, it showed that the value of $\mathrm{IC}_{50}$ is 68.50 ppm. On the formula 1 (aqupec $505 \mathrm{HV} 0.5 \%$ ), the value of $\mathrm{IC}_{50}$ is $189.32 \mathrm{ppm}$. On the formula 2

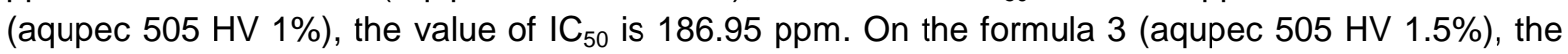
value of $\mathrm{IC}_{50}$ is $184.75 \mathrm{ppm}$. On the formula 4 (aqupec $505 \mathrm{HV} 2 \%$ ), the value of $\mathrm{IC}_{50}$ is $186.60 \mathrm{ppm}$. On the formula 5 (aqupec $505 \mathrm{HV} 1.5 \%$ regularly), the value of $\mathrm{IC}_{50}$ is $174.73 \mathrm{ppm}$. The results of this study showed that the gel which was made was safe to use and the most effective one was on the formula 5 which obtained $\mathrm{IC}_{50}$ as many as $186.60 \mathrm{ppm}$.
\end{abstract}

Keywords: Antioxidant; Cherry extract; Gel; Aqupec 505 HV.

\section{Introduction}

In Indonesian, cancer, heart disease, diabetes, and degenerative diseases are increasingly becoming widespread. One of them is caused by free radical. Up to now, the exposure of free radical is quite extensive in people's lives such as, pollution and unhealthy food. One of antidotes of free radicals is an antioxidant (Winarsi, 2007).

Antioxidant is inhibitors of oxidation reaction by free radical that can damage unsaturated fatty acids, wall membrane, blood vessel, DNA bases, and lipid tissue, causing disease. The method used for antioxidant testing was the DPPH radical capture method. The parameters used for the measurement of the antioxidant activity of Cherry were radical capture percent and $I_{50}$ which were measured using UV-Vis spectrophotometer (Salamah \& Widyasari, 2015). 
Cherry is considered to have high antioxidant activity due to its natural anthocyanin content. Anthocyanin is a sub class of flavonoid which is important for a plant. Cherry also contains several other polyphenol compounds such a tannin (Zhang \& Lin, 2009). Antioxidant is well applied in cosmetics, one of those is in a gel form.

Gel has several advantages, namely it is nonsticky, can be applied easily, easily washed, does not leave a layer of oil on the skin, the viscosity of the gel does not change during storage (Sihombing et al., 2013).

Gel consists of basic ingredients and additives. One of the basic ingredients of gel is Aqupec. Aqupec is an acrylic acid polymer that can increase viscosity at small concentrations, as well as increase gel stability (Wathoni, 2012). Aqupec is an acrylic acid polymer that can increase viscosity at small concentrations, as well as increase gel stability (Carter, 1995).

Based on Herni \& Rahardjo (2014) research it seen that Cherry contains active compounds including polyphenols. Polyphenol is one of the compounds that have natural antioxidant activity, kersen fruit extract has an $\mathrm{IC}_{50}$ value of $12.84 \mathrm{ppm}$ while it has an $\mathrm{IC}_{50}$ value of $319.89 \mathrm{ppm}$, from the results of these studies, Kersen fruit has a very strong antioxidant activity and has more potential to be developed as antioxidant. Therefore, this study is aimed to determine the stability of the cherry extract or gel preparations with a difference base of aqupec $505 \mathrm{HV}$ with routine comparison.

\section{Materials and Methods}

\section{Population and Sample}

The sample used in this study was the extract of Cherry (Muntingia calabura L.) gel with aqupec $505 \mathrm{HV}$ base with a concentration of $0.5 \% ; 1 \% ; 1.5 \%$ and $2 \%$.

\section{Research variable}

\section{Classification of variables}

The independent variable in this study was a formulation with aqupec $505 \mathrm{HV}$ base variation and a concentration of $0.5 \% ; 1 \% ; 1.5 \%$ and $2 \%$ for making antioxidant gel.
The controlled variable was Cherry extract (where plants grow, plant age), mixed composition, methods and processes of making antioxidant gels along with ingredients and analytical tools.

Dependent variable was the stability of gel, physical quality of gel (organoleptic, homogeneity, viscosity, spreadability, adhesion and $\mathrm{pH}$ ) and antioxidant activity power of Cherry.

\section{The operational definition of the main variable}

Cherry Extract was made by reflux method with $70 \%$ ethanol solvent. Cherry was obtained from the East Penfui area of Kupang Regency. Manufacture of antioxidant gels used the Aquapec $505 \mathrm{HV}$ base.

\section{Methodology}

\section{Plant Determination}

Determination and identification were based on morphological features that existed in plants on the literature as evidenced in the Phytochemical Laboratory of Pharmacy, Kupang Health Polytechnic of Health Ministry.

\section{Drying Simplicia}

Cherry was sorted and washed with water so that the dirt attached to the leaves was lost, then it was roasted at $40^{\circ} \mathrm{C}$.

Simplisia that was already dry was then pollinated with a pollinator and sieved in mesh 40 then weighed to determine the dry percent weight to wet weight.

\section{Determination of the moisture content of the Cherry powder}

Determination of moisture content was done by weighing the Cherry powder with 2 grams of moisture content using a moisture balance tool.

\section{Making Cherry extract}

The production of 50grams of Cherry powder were refluxed with $70 \%$ ethanol solvent and refluxed for 1 hour.

\section{Determination of the moisture content of the Cherry extract}

Determination of moisture content was done by extracting Cherry weighed 2 grams of 
Int J Adv Life Sci Res. Volume 4(1)23-33

moisture content measured using a moisture balance tool.

\section{Determination of organoleptic extract of Cherry}

Determination of organoleptic in Cherry extract by observing the color, odor, and shape of the $70 \%$ ethanol extract of Cherry.

\section{Alcohol free test of Cherry extract}

The $70 \%$ ethanol-free test of concentrated extract of Cherry aimed to ensure that the concentrated extract of Cherry was free of $70 \%$ ethanol by an esterification reaction. Acetic acid and concentrated sulfuric acid were added into the test tube containing the extract, then it was heated. If a typical ester smell of alcohol was detected, the extract still contained $70 \%$ ethanol.

\section{Identification of chemical content of Cherry extract}

Identification of Cherry chemical content could be done with two events, namely by reagents and TLC, identification of polyphenols, flavonoids,

\section{The design of the antioxidant gel formulation of Cherry ethanol extract}

The gel formulation was then made on the basis of Aqupec $505 \mathrm{HV}$ with various concentrations of $0.5 \% ; 1 \% ; 1.5 \%$ and $2 \%$. The design of the antioxidant gel formula can be seen in table 1 .

Table 1. The draft formula of the antioxidant gel extract of Cherry

\begin{tabular}{|c|c|c|c|c|c|}
\hline Ingredients & $\mathrm{F}_{1}$ & $\mathrm{~F}_{2}$ & $\mathrm{~F}_{3}$ & $\mathrm{~F}_{4}$ & $\mathrm{~F}_{5}$ \\
\hline Aqupec 505 HV & $0.5 \mathrm{~g}$ & $1 \mathrm{~g}$ & $1.5 \mathrm{~g}$ & $2 \mathrm{~g}$ & $1.5 \mathrm{~g}$ \\
\hline TEA & $2 \mathrm{~g}$ & $2 \mathrm{~g}$ & $2 \mathrm{~g}$ & $2 \mathrm{~g}$ & $2 \mathrm{~g}$ \\
\hline Glycerin & $30 \mathrm{~g}$ & $30 \mathrm{~g}$ & $30 \mathrm{~g}$ & $30 \mathrm{~g}$ & $30 \mathrm{~g}$ \\
\hline Nipagin & $0.2 \mathrm{~g}$ & $0.2 \mathrm{~g}$ & $0.2 \mathrm{~g}$ & $0.2 \mathrm{~g}$ & $0.2 \mathrm{~g}$ \\
\hline Propylene glycol & $5 \mathrm{~g}$ & $5 \mathrm{~g}$ & $5 \mathrm{~g}$ & $5 \mathrm{~g}$ & $5 \mathrm{~g}$ \\
\hline Leaf Extract & $10 \%$ & $10 \%$ & $10 \%$ & $10 \%$ & - \\
\hline Cherry & & & & & \\
\hline Routine & - & - & - & - & $1 \%$ \\
\hline Aquadest & 52.3 & 51.8 & 51.3 & 50.8 & 60.3 \\
\hline Total & 100 & 100 & 100 & 100 & 100 \\
\hline
\end{tabular}

\section{The process of gel production}

Aqupec was used as a gel base with hot aquadest in a hot mortar then TEA (triethanolamine) was added and then crushed until homogeneous. Then Glycerin was added and propylene glycol as humectants in mortar that had been filled with aqupec and triethanolamine, crushed until homogeneous then finely crushed nipagin was added as a preservative, crushed until homogeneous. Cherry Extract as an active antioxidant was added and stirred homogeneously to form a good gel (Burke, 2007).

The physical properties test of antioxidant gel ethanol extract of Cherry Fruit.

\section{Antioxidant activity test}

Stock solution (Cherry extract, Cherry extract gel, routine standard) was made into 5 series of dilutions of $0.4 \mathrm{mM}$ each. The mixture was incubated during the operating time and its absorbance was recorded on the length of the physical test of Kersen ethanol antioxidant gel included: organoleptic test, homogeneity test, spreadability test, viscosity test, stickiness test, $\mathrm{pH}$ test, gel stability test and activity test radical capture and antioxidant activity Test

\section{Analysis Techniques}

The antioxidant activity of DPPH free radical data (\%) extract or gel of Cherry was calculated by Probit method from linear regression equation and determine its IC50. The scavenging activity of DPPH free radicals was calculated by the formula:

$$
\begin{aligned}
& \text { Scavenging activity }(\%)= \\
& \text { absorbance of (blank }- \text { sample) } \times 100 \%
\end{aligned}
$$

absorbance of blank 
Int J Adv Life Sci Res. Volume 4(1)23-33

Results

\section{Determination results and description of Cherry}

Identification of Cherry (Muntingia calabura L.) plant was carried out at the Phytochemical
Laboratory of Pharmacy program, Kupang Health Polytechnic of Health Ministry. The key result of the plant determination was done following the method by Steenis et al. (2002).

\section{Simplisia drying result}

Table 2. Yields of the Cherry powder

\begin{tabular}{ccc}
\hline $\begin{array}{c}\text { Gross weight } \\
\text { (gram) }\end{array}$ & $\begin{array}{c}\text { Dry weight } \\
(\text { gram })\end{array}$ & $\begin{array}{c}\text { Percentage of yield } \\
(\%)\end{array}$ \\
\hline 3500 & 950 & 27
\end{tabular}

\section{Identification results of Cherry powder}

Organoleptic identification results can be seen in table 3 .

Table 3. Organoleptic identification results of Cherry powder

\begin{tabular}{ll}
\hline Identification types & Result \\
\hline Shape & Powder \\
Color & Brown \\
Smell & Typical \\
Taste & No taste \\
\hline
\end{tabular}

\section{The determination result of powder moisture content.}

The determination result of moisture content can be seen in table 4 .

Table 4. The determination result of moisture content of Cherry powder

\begin{tabular}{ccc}
\hline No & Weight of Simplicia powder (gram) & Percentage of moisture content (\%) \\
\hline 1 & 2.00 & 6.90 \\
2 & 2.00 & 7.40 \\
3 & 2.00 & 4.70 \\
\hline & Average \pm SD & $6.30 \pm 1.44$ \\
\hline
\end{tabular}

The results of $70 \%$ ethanol extract of Cherry Production

Table 5. Yields of the Kersen Fruit extract

\begin{tabular}{ccc}
\hline Powder weight (gram) & Extract weight (gram) & Percentage of yield (\%) \\
\hline 800 & 121.548 & 15.19 \\
\hline
\end{tabular}

\section{Identification results of Cherry extract}

Organoleptic identification results of Cherry extract.

Table 6. Organoleptic identification results of Cherry extract.

\begin{tabular}{cc}
\hline Identification Type & Result \\
\hline Shape & Thick extract \\
Color & Brown \\
Smell & Typical \\
Test & Bitter \\
\hline
\end{tabular}


The results of determining the moisture content of the Kersen Fruit extract.

Table 7. The results of determining the moisture content of kersen fruit extract

\begin{tabular}{ccc}
\hline No & Extract weight (gram) & Percentage of moisture content (\%) \\
\hline 1 & 2.00 & 9.10 \\
2 & 2.00 & 7.50 \\
3 & 2.00 & 7.90 \\
\hline & Average \pm SD & $8.16 \pm 0.83$ \\
\hline
\end{tabular}

\section{Alcohol-free identification results of Cherry extract}

The results of alcohol free identification of Cherry extract can be seen in table 8 .

Table 8. Results of alcohol free identification of Kersen Fruit extract

\begin{tabular}{ccc}
\hline Ingredient & References (Ansel 1989) & Result \\
\hline Alcohol & $\begin{array}{c}\text { Typical smell of esters from alcohol } \\
\text { There is no characteristic smell of } \\
\text { Extract }\end{array}$ & $\begin{array}{c}\text { Typical smell of esters from alcohol } \\
\text { There is no characteristic smell of } \\
\text { esters from alcohol }\end{array}$ \\
\hline
\end{tabular}

Results of chemical identification with reagents.

Table 9. Results of identification of chemical content in Cherry extracts by recording

\begin{tabular}{|c|c|c|c|c|c|c|c|}
\hline No & $\begin{array}{c}\text { Content } \\
\text { Chemistry }\end{array}$ & \multicolumn{2}{|c|}{ Procedure } & Result & \multicolumn{2}{|c|}{ References } & Note \\
\hline 1. & Polyphenols & \multicolumn{2}{|c|}{ Extract + aquadest } & Shapes & \multicolumn{2}{|c|}{ Shapes } & + \\
\hline & & $+\mathrm{FeCl}_{3}$ & & Black & Color & Purple & \\
\hline & & & & & - black & & \\
\hline 2. & Flavonoids & Mg powder, & alcohol: & Shapes & Red, & & - \\
\hline & & $\begin{array}{l}\text { hydrochloric } \\
\text { acid }\end{array}$ & (1:10), & Green & Orange & Or & \\
\hline & & amil alcohol & & & Yellow & & \\
\hline
\end{tabular}

Chemical identification results by thin layer chromatography (TLC).

Table 10. Results of identifying chemical contents in extracts by TLC

\begin{tabular}{|l|l|l|l|l|}
\hline \multirow{2}{*}{ Compound } & & Result & & Note \\
\cline { 2 - 4 } & & & & \\
\hline \multirow{2}{*}{ Flavonoids } & UV 254 nm & UV 366 nm & Spray reagents & \\
\hline & Colored patches & Patches & Sitoborate & \\
\hline & Dark & Fluorescence & Yellow & \\
\hline Polyphenols & colored patches & Patches & Ferric Chloride & + \\
\hline & Dark & Fluorescence & (gray black color) & + \\
\hline
\end{tabular}

\section{Gel physical quality test results}

The physical quality tests of the gel include organoleptic observations, gel homogeneity tests, viscosity tests, dispersion tests, adhesion tests, and $\mathrm{pH}$ tests.

\section{Organoleptic gel test results.}

A good gel preparation has an attractive color, pleasant smell, and good consistency for comfortable use. The results obtained for organoleptic gel identification can be seen in table 11 . 
Int J Adv Life Sci Res. Volume 4(1)23-33

Table 11. Organoleptic gel test results

\begin{tabular}{|c|c|c|c|c|c|c|}
\hline \multirow{2}{*}{ Formula } & \multicolumn{2}{|c|}{ Color } & \multicolumn{2}{|r|}{ Smell } & \multicolumn{2}{|c|}{ Consistency } \\
\hline & Day 1 & Day 21 & Day 1 & Day 21 & Day 1 & Day 21 \\
\hline Formula 1 & Brown & Brown & Typical & Typical & A little thick & A little thick \\
\hline Formula 2 & Brown & Brown & Typical & Typical & Rather Thick & Rather Thick \\
\hline Formula 3 & Brown & Brown & Typical & Typical & Thick & Thick \\
\hline Formula 4 & Brown & Brown & Typical & Typical & Very Thick & Very Thick \\
\hline Formula 5 & Yellow & yellow & Typical & Typical & Thick & Thick \\
\hline \multicolumn{7}{|l|}{ Notes: } \\
\hline ormula 1 & \multicolumn{6}{|c|}{ : gel with gelling agent Aqupec 505 HV 0.5\% } \\
\hline Formula 2 & \multicolumn{6}{|c|}{ : gel with gelling agent Aqupec 505 HV 1\% } \\
\hline Formula 3 & \multicolumn{6}{|c|}{ : gel with gelling agent Aqupec 505 HV 1.5\% } \\
\hline Formula 4 & \multicolumn{6}{|c|}{ : gel with gelling agent Aqupec 505 HV 2\% } \\
\hline Formula 5 & \multicolumn{6}{|c|}{ : gel with gelling agent Aqupec 505 HV $1.5 \%$ with routine } \\
\hline
\end{tabular}

A gel with very thick consistency is found in formula 4 using aqupec $505 \mathrm{HV}$ is greater, and rather thick is found in formula 1 because aqupec $505 \mathrm{HV}$ is used less. The greater concentration of aqupec $505 \mathrm{HV}$ is used to produce a gel with a thicker consistency.

\section{Gel homogeneity test results.}

The observations of the gel homogeneity test result can be seen in table 12 .

Table 12. Results of gel homogeneity test

\begin{tabular}{ccc}
\hline Formula & \multicolumn{2}{c}{ Homogeneity } \\
\cline { 2 - 3 } & Day 1 & Day 2 \\
\hline Formula 1 & Homogeneous & Homogeneous \\
Formula 2 & Homogeneous & Homogeneous \\
Formula 3 & Homogeneous & Homogeneous \\
Formula 4 & Homogeneous & Homogeneous \\
Formula 5 & Homogeneous & Homogeneous \\
\hline
\end{tabular}

Notes

Formula 1 : gel with gelling agent Aqupec 505

Formula 2 : gel with gelling agent Aqupec 505

Formula 3 : gel with gelling agent Aqupec 505

Formula 4 : gel with gelling agent Aqupec 505

HV $0.5 \%$

HV $1 \%$

HV $1.5 \%$

HV $2 \%$

Formula 5 : gel with gelling agent Aqupec 505 HV 1.5\% with routine

\section{Gel viscosity test results}

The results of observations on the viscosity test of Kersen Fruit extract gel can be seen in table 13 .

Table 13. Test results of viscosity of the Kersen Fruit extract gel

\begin{tabular}{lccccc}
\hline Identification & \multicolumn{5}{c}{ Viscosity (d Pas) \pm SD } \\
\cline { 2 - 6 } Time & Formula 1 & Formula 2 & Formula 3 & Formula 4 & Formula 5 \\
\hline Day 1 & 176.67 & 295.35 & $335.43 \pm$ & 493.53 & 363.30 \\
& \pm 28.968 & \pm 11.648 & \pm 29.968 & \pm 56.965 & \pm 11.758 \\
Day 21 & 195.30 & 278.67 & 325.33 & 475.33 & 312 \\
& \pm 11.748 & \pm 25.268 & 25.367 & \pm 47.658 & \pm 36.259 \\
\hline
\end{tabular}

Notes :

Formula 1 : gel with gelling agent Aqupec $505 \mathrm{HV} 0.5 \%$

Formula 2 : gel with gelling agent Aqupec 505 HV 1\%

Formula 3 : gel with gelling agent Aqupec $505 \mathrm{HV} 1.5 \%$

Formula $4 \quad$ : gel with gelling agent Aqupec 505 HV 2\%

Formula 5 : gel with gelling agent Aqupec $505 \mathrm{HV}$ 1.5\% with routine 
Observation results show that viscosity in formula 2, formula 3, formula 4, and formula 5 decreased on the 21 st day which is caused due to effect of temperature and pressure by the storage of gel. The increase in temperature will increase the distance between the atoms so that the force between the atoms will decrease, causing the viscosity of the preparation to decrease while in formula 1 viscosity increased on the 21 st day due to improper storage which is due to the effects of inappropriate room temperature which causes the gel to become thicker and less stable in storage.

Gel spread test results.

Table 14. Test spread results of Cherry extract gel

\begin{tabular}{|c|c|c|c|c|}
\hline \multirow{2}{*}{ Formula } & \multirow{2}{*}{ Load (gram) } & \multicolumn{3}{|c|}{ Spread diameter $(\mathrm{cm}) \pm \mathrm{SD}$} \\
\hline & & \multicolumn{2}{|l|}{ Day 1} & Day 21 \\
\hline & - & 5.123 & \pm 0.712 & $4.268 \pm 0.670$ \\
\hline & 50 & \multicolumn{2}{|c|}{$5.625 \pm 0.825$} & $4.913 \pm 0.475$ \\
\hline \multirow[t]{5}{*}{ Formula I } & 100 & \multicolumn{2}{|c|}{$6.214 \pm 0.675$} & $5.166 \pm 0.472$ \\
\hline & 150 & 6.576 & \pm 0.650 & $5.815 \pm 0.535$ \\
\hline & 200 & \multicolumn{2}{|c|}{$7.124 \pm 0.512$} & $5.936 \pm 0.563$ \\
\hline & - & \multicolumn{2}{|c|}{$2.813 \pm 0.264$} & $3.469 \pm 0.183$ \\
\hline & 50 & 3.456 & \pm 0.163 & $3.976 \pm 0.435$ \\
\hline \multirow[t]{5}{*}{ Formula 2} & 100 & \multicolumn{2}{|c|}{$3.714 \pm 0.621$} & $4.265 \pm 0.563$ \\
\hline & 150 & \multicolumn{2}{|c|}{$4.051 \pm 0.571$} & $4.415 \pm 0.615$ \\
\hline & 200 & \multicolumn{2}{|c|}{$4.324 \pm 0.735$} & $4.823 \pm 0,645$ \\
\hline & - & 2.546 & \pm 0.186 & $2.654 \pm 0.345$ \\
\hline & 50 & 2.67 & \pm 0.135 & $2.784 \pm 0.386$ \\
\hline \multirow[t]{5}{*}{ Formula 3} & 100 & 2.953 & \pm 0.162 & $3.256 \pm 0.282$ \\
\hline & 150 & $3.25 \pm$ & 0.175 & $3.424 \pm 0.292$ \\
\hline & 200 & 3.34 & \pm 0.12 & $3.843 \pm 0.417$ \\
\hline & - & $1.61 \pm$ & 0.453 & $2.14 \pm 0.216$ \\
\hline & 50 & 1.786 & \pm 0.564 & $2.346 \pm 0.217$ \\
\hline \multirow[t]{5}{*}{ Formula 4} & 100 & 1.959 & \pm 0.562 & $2.521 \pm 0.293$ \\
\hline & 150 & \multicolumn{2}{|c|}{$2.235 \pm 0.467$} & $2.623 \pm 0.2894$ \\
\hline & 200 & 2.456 & \pm 0.324 & $2.789 \pm 0.267$ \\
\hline & - & 2.353 & \pm 0.173 & $2.425 \pm 0.357$ \\
\hline & 50 & 2.583 & \pm 0.298 & $2.656 \pm 0.342$ \\
\hline \multirow[t]{3}{*}{ Formula 5} & 100 & \multicolumn{2}{|c|}{$3.725 \pm 0.376$} & $2.833 \pm 0.230$ \\
\hline & 150 & 3.243 & \pm 0.347 & $3.095 \pm 0.189$ \\
\hline & 200 & 3.563 & \pm 0.254 & $3.315 \pm 0.467$ \\
\hline
\end{tabular}

\begin{tabular}{|c|c|}
\hline$\overline{\text { Notes }}$ & : \\
\hline Formula 1 & : gel with gelling agent Aqupec 505 HV 0.5\% \\
\hline Formula 2 & : gel with gelling agent Aqupec $505 \mathrm{HV} 1 \%$ \\
\hline Formula 3 & : gel with gelling agent Aqupec 505 HV 1.5\% \\
\hline Formula 4 & $\begin{array}{l}\text { : gel with gelling agent Aqupec } 505 \mathrm{HV} 2 \% \\
\quad \text { : gel with gelling agent Aqupec }\end{array}$ \\
\hline
\end{tabular}

Formula 5 505

HV $1.5 \%$ and with routine 
Int J Adv Life Sci Res. Volume 4(1)23-33

The measurement results of gel spread shows that the spread power was inversely proportional to viscosity, the greater the viscosity, the smaller the spread power and vice versa.

The data above shows that Formula 4 has a lower spread yield, while Formula 1 has the greatest spread yield because the greater the concentration of aqupec $505 \mathrm{HV}$, the smaller the spread power. The increased concentration of aqupec $505 \mathrm{HV}$ causes the value of the spread power to be smaller, and the gel to be stronger.

Gel adhesion test results.

The measurement results can be seen in table 15 .

Table 15. Results of gel adhesion test of Kersen Fruit extract

\begin{tabular}{llllll}
\hline \multirow{2}{*}{$\begin{array}{l}\text { Test } \\
\text { Time }\end{array}$} & \multicolumn{5}{c}{$\begin{array}{c}\text { Adhesion power } \\
\text { (seconds) }\end{array}$} \\
\cline { 2 - 6 } & Formula 1 & Formula 2 & Formula 3 & Formula 4 & Formula 5 \\
\hline Day 1 & $3.12 \pm 0.64$ & $6.28 \pm 1.02$ & $10.98 \pm 1.26$ & $16.39 \pm 2.28$ & $10.99 \pm 0.82$ \\
Day 21 & $3.69 \pm 0.34$ & $8.90 \pm 1.28$ & $12.68 \pm 1.36$ & $19.48 \pm 1.76$ & $11.98 \pm 1.69$ \\
\hline Notes & $:$ & & & \\
Formula 1 & $:$ gel with gelling agent Aqupec 505 & HV 0.5\% & \\
Formula 2 & $:$ gel with gelling agent Aqupec 505 & HV 1\% & \\
Formula 3 & $:$ gel with gelling agent Aqupec 505 & HV 1.5\% & \\
Formula 4 & $:$ gel with gelling agent Aqupec 505 & HV 2\% & \\
Formula 5 & $:$ gel with gelling agent Aqupec 505 & HV 1.5\% & \\
\end{tabular}

Formula 4 has the greatest adhesion compared to other formulas, while the smallest adhesion is in formula 1. The addition of aqupec $505 \mathrm{HV}$ can increase the gel adhesion, because the aqupec 505 HV's thick nature causes molecule which is bound through dipole-dipole interactions to increasingly elongate and the molecular weight becomes larger so as to produce a gel that is getting stronger with longer adhesion.

\section{Gel pH Test Result.}

The $\mathrm{pH}$ test is carried out to find out the $\mathrm{pH}$ value of the gel to match the $\mathrm{pH}$ of the skin. The results of $\mathrm{pH}$ testing of Kersen Fruit extract gel can be seen in table 16.

Table 16. Test results for the $\mathrm{pH}$ of the Kersen Fruit extract gel

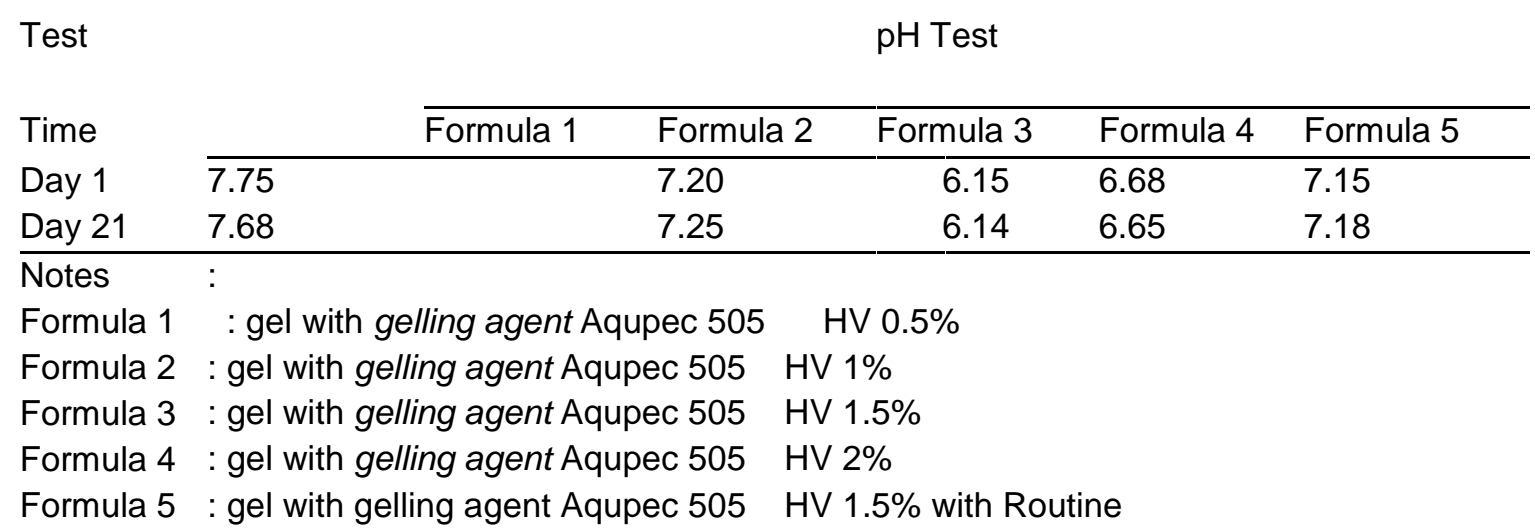


In formula 4 and formula 5 the $\mathrm{pH}$ decreases. The decrease in $\mathrm{pH}$ is probably caused by the influence of the environment such as gases in the air which are acidic that enter the gel, but the decrease in $\mathrm{pH}$ that occurs in each formula is not too significant and so it can be said that $\mathrm{pH}$ is relatively stable based on SNI 16-4399-1996 pH in the skin ranges from 4.5 to 8.0 (Sriningsih et al., 2014).

Gel stability test results

Table 17. Organoleptic test results of Kersen Fruit extract gel stability with various concentrations of Aqupec $505 \mathrm{HV}$ using the freeze thaw method

\begin{tabular}{cccccc}
\hline Cycle & Formula 1 & Formula 2 & Formula 3 & Formula 4 & Formula 5 \\
\hline 1 & - & - & - & - & - \\
2 & - & - & - & - & - \\
3 & - & - & - & - & - \\
4 & - & - & - & - & - \\
5 & - & - & - & - & - \\
\hline
\end{tabular}

$\begin{array}{lll}\text { Notes } & : & \\ - & =\text { No separation occurred } \\ \text { Formula 1 } & : \text { gel with gelling agent Aqupec } 505 \mathrm{HV} 0.5 \% \\ \text { Formula 2 } & : \text { gel with gelling agent Aqupec } 505 \mathrm{HV} 1 \% \\ \text { Formula 3 } & : \text { gel with gelling agent Aqupec } 505 \mathrm{HV} 1.5 \% \\ \text { Formula 4 } & : \text { gel with gelling agent Aqupec } 505 \mathrm{HV} 2 \% \\ \text { Formula 5 } & : \text { gel with gelling agent Aqupec } 505 \mathrm{HV} 1.5 \% \text { with routine }\end{array}$

\section{Testing antioxidant activity with the DPPH method}

The results of testing antioxidant activity carried out on day 1 and day 21 can be seen in table 18 .

Table 18. Results of the antioxidant activity of the Cherry extract gel

\begin{tabular}{ccc}
\hline & & $\mathrm{IC}_{50}(\mathrm{ppm})$ \\
\cline { 3 - 3 } \cline { 3 - 3 } Sample & Day 1 & Day 21 \\
Routine & 6.29 & - \\
Cherry Extract & 68.50 & - \\
Formula 1 & 189.32 & 190.95 \\
Formula 2 & 186.95 & 192.38 \\
Formula 3 & 184.75 & 189.25 \\
Formula 4 & 186.60 & 187.54 \\
Formula 5 & 174.73 & 189.02 \\
\hline
\end{tabular}

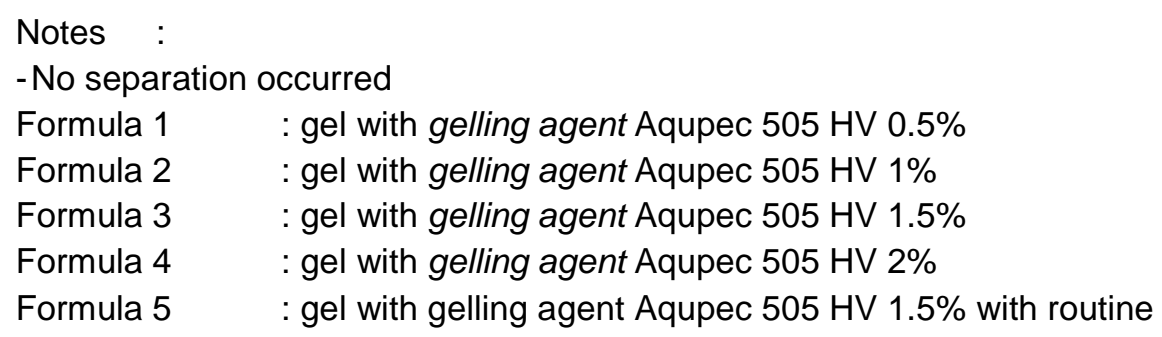

\section{Discussion}

The results of testing the antioxidant activity of Cherry extract amounted to $67.48 \mathrm{ppm}$ which means that the Cherry Extract has a strong antioxidant activity (Molyneux 2004).
Cherry has high antioxidant property due to the presence of anthocyanin content. Along with that cherry also contains many polyphenol such as tannin (Zhang \& Lin, 2009). The Gel formula has several usefulness and can be easily applied on skin (Sihombing et al., 2013). The main component of gel is Aqupec that can 
increase viscosity at small concentrations, as well as increase gel stability (Wathoni, 2012), at small concentrations, as well as increase gel stability (Carter, 1995).

Numerous clinical studies have stated that the consumption of cherries and their derivatives has a positive effect on human health. Again in vitro studies have shown that natural polyphenols-rich sweet cherry extracts can protect endothelial cells from oxidative stress. Moreover, cherry extracts were detected to be a useful anti-inflammatory synthetic drug (Beconcini et al., 2020).

\section{Conclusion}

First, the extract of Cherry (Muntingia calabura L.) leaf can be formulated into a gel with a variation of aqupec $505 \mathrm{HV}$ base concentration which has stable physical quality and gel preparation stability.

Secondly, Cherry (Muntingia calabura L.) leaf extract gel has antioxidant activity. Formula 1 (aqupec $505 \mathrm{HV} 0.5 \%$ ) has an $\mathrm{IC}_{50}$ value of $187.21 \mathrm{ppm}$, formula 2 (aqupec $505 \mathrm{HV}$ 1\%)

\section{References}

Beconcini, D., Felice, F., Fabiano, A., Sarmento, B., Zambito, Y., \& Di Stefano, R. (2020). Antioxidant and anti-inflammatory properties of cherry extract: nanosystems-based strategies to improve endothelial function and intestinal absorption. Foods, 9(2), 207.

Cooper, J. W. (1967). Cooper and gunn's dispensing for pharmaceutical students. Pitman Medical Publishing Company.

Draelos, Z. D. (2005). Cosmetic formulation of skin care products (pp. 25-26). CRC Press.

Marliani, L. (2014). Aktivitas antioksidan daun dan buah jamblang (syzigium cumini I.) Skeel. Prosiding SNaPP: Sains, Teknologi, 4(1), 201-206.

Molyneux, P. (2004). The use of the stable free radical diphenylpicrylhydrazyl (DPPH) for estimating antioxidant activity. Songklanakarin J. sci. technol, 26(2), 211-219.

Salamah, N., \& Widyasari, E. (2015). Aktivitas antioksidan ekstrak metanol daun kelengkeng (Euphoria longan (L) Steud.) dengan metode penangkapan radikal 2, 2'-difenil-1pikrilhidrazil. Pharmaciana, 5(1), 25-34. has an IC50 value of $184.81 \mathrm{ppm}$, formula 3 (aqupec $505 \mathrm{HV} 1.5 \%$ ) has an $\mathrm{IC}_{50}$ value of 182.55 ppm, formula 4 (aqupec 505 HV 2\%) has an $\mathrm{IC}_{50}$ value of $184.49 \mathrm{ppm}$, and formula 5 (aqupec 505 HV 1.5\% with routine) has an $\mathrm{IC}_{50}$ value of $172.52 \mathrm{ppm}$. The formula Cherry extract gel has weak antioxidant activity.

It has been found that the Cherry extract gel formula has weak antioxidant activity. For further study, preparations must be made other than gels such as creams and tablets. It is necessary to do further research on the antioxidant gel of Cherry extract by using methods other than DPPH to find out the potential of antioxidant against other types of radicals.

\section{Acknowledgments}

The authors acknowledge Department of Pharmacy, Kupang Health Polytechnic of Health Ministry, Indonesia for their support.

\section{Conflicts of Interest}

The authors declare that there are no conflicts of interest.

Seribu, D. K. (2006). Ansel, HC, 1989, Pengantar Bentuk Sediaan Farmasi, Edisi III, 602, 607-612, Departemen Kesehatan RI, Jakarta. Anonim, 1986, Sediaan Galenik, 5-17, Departemen Kesehatan RI, Jakarta. Anonim, 2002, Free Radical and Your Health (online). Food Chem, 83, 547-550.

Sihombing, C. N., Nasrul, W., \& Taofik, R. (2010). Formulasi Gel Antioksidan Ekstrak Buah Buncis (Phaseolus vulgaris L.) dengan Menggunakan Basis Aqupec 505 HV. Jurnal ilmiah universitas padjadjaran.

Sriningsih. 2008. Analisa Senyawa Golongan Flavonoid dari Daun Dewan daru (Eugenia uniflora L.). Skripsi. Tersediadalam

van Steenis, C. G. G. J., Bloembergen, S., \& Eyma, P. J. (2002). Flora, diterjemahkan oleh Surjowinoto. M., Hardjosuwarno, S., Adisewojo, SS, Wibisono, Partodidjojo, M., Wirjahardja, S., cetakan, 8, 378-382.

Wathoni N, Rusdiana T, Hutagaol RY. 2012. Formulasi Gel Antioksi dan Ekstrak Rimpang Lengkuas (Alpinia galanga L.Willd) dengan Menggunakan Basis Aqupec 505 HV.Jatinangor Fakultas Farmasi, Universitas Padjadjran 
Winarsi, H. (2007). Antioksidan alami \& radikal bebas.

Zhang, L. L., \& Lin, Y. M. (2009). Antioxidant tannins from Syzygium cumini fruit. African Journal of Biotechnology, 8(10). 